\title{
Large Eared Grebe Colony At Regina, 1962
}

by Fred W. Lahrman, Sask. Museum of Natural History

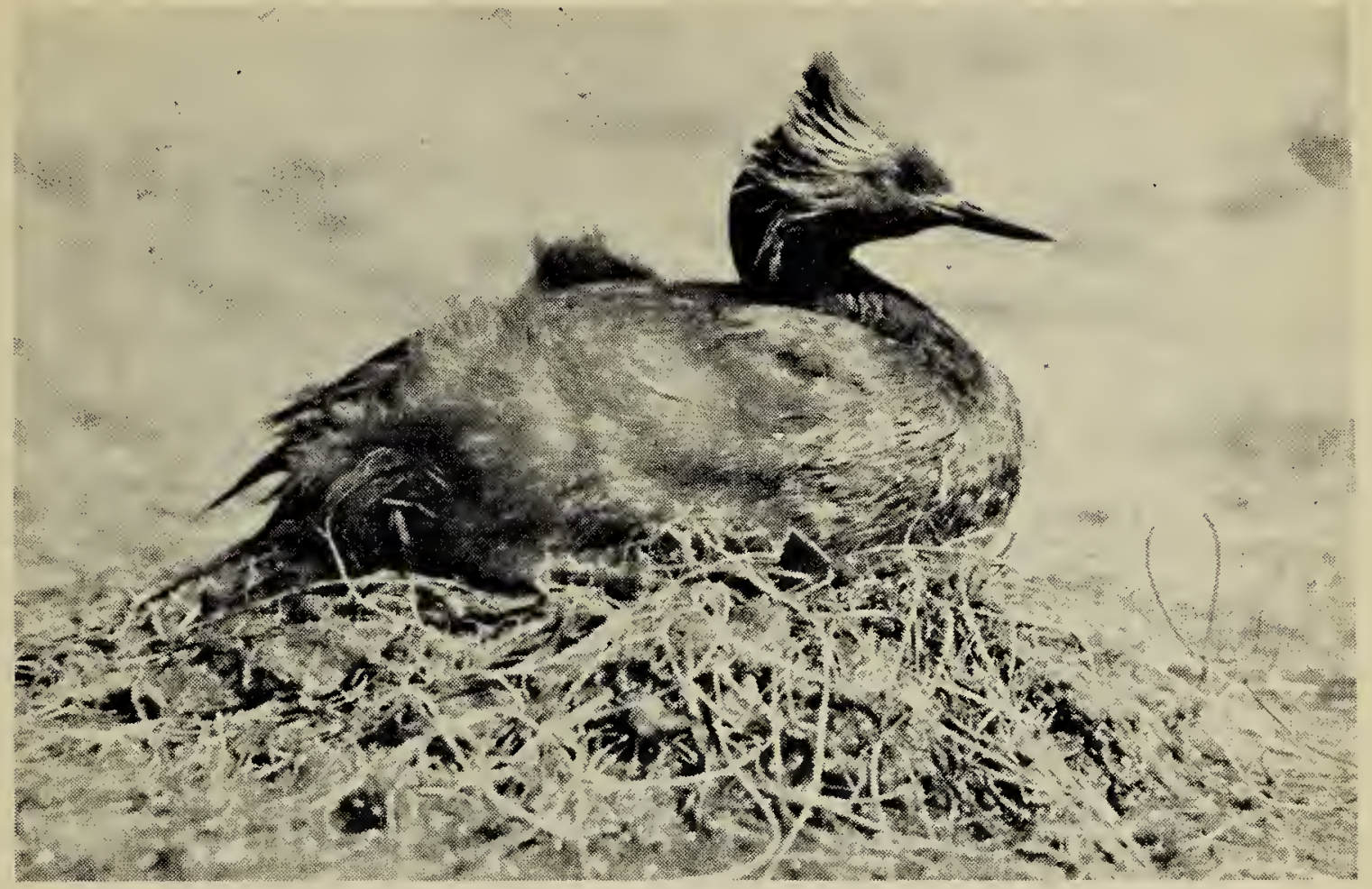

Eared Grebe on nest at Regina Waterfowl Park, 1962

Last year we reported an Eared Grebe colony at the Regina Waterfowl Park where a total of 48 nests were under observation during the summer (Blue Jay, 19:170-171). This colony was of local interest because no large colony of Eared Grebes had been noted in the Wascana marshes since the 40's and early 50's, when up to 25-30 pairs nested. The extent of the 1962 colony at the Regina Waterfowl Park was even more striking37 nests east of the Broad Street bridge, 8 nests east of the pipeline at the city power house, 106 nests north of "Goose Island" (the largest island in the park), and 14 south of Goose
Island-a grand total of 165 nests.

The first Eared Grebes to arrive in the area were seen on April 25, 1962, by Margaret Belcher and Maureen Rever, in a great influx of diving ducks-several birds being noted on Wascana Lake and several at the Waterfowl Park. By June 8, I saw that the grebes were building nests, and on July 5 I counted 165 nests in the location described above. On July 13 most. of the grebes had hatched, and only a few grebes were still on their nests. The small colony south of Goose Island was started later, and the young there hatched by July 30 th.

\section{LOGGERHEAD SHRIKE versus BREWER'S BLACKBIRD}

\section{by Bernard C. Haysom, Regina}

On May 12, 1962, Bob 'McCall and I observed a Loggerhead Shrike in a small grove of trees on the Regina Golf Course briefly attack a Brewer's Blackbird. A male blackbird flew into the grove and landed in the same tree in which the Shrike was perched. The shrike seemed to frighten the blackbird for it flew away at once, landing on the ground at a distance of about 30 feet. Hardly had the blackbird settled on the ground when the shrike flew up about 25 feet in the air and then went into a power dive with the blackbird as the target. The attack appeared to be an effort to drive the blackbird away for the shrike struck quite hard at the blackbird. The blackbird went up about three feet in the air then flew rapidly away. The shrike returned to perch in the same tree. Birds on territory frequently drive off species larger than themselves and we presume that the shrike was on its territory in this case. Even so, we were surprised to see an encounter of this nature. 